\title{
Evaluation of New Insecticide Molecules against Rice Yellow Stem Borer Scirpophaga incertulas Walker (Pyralidae: Lepidoptera) under Faizabad Condition
}

\author{
Yadav Abhinandan* and P. K. Gupta \\ Department of Entomology, NDUAT, Kumarganj, Faizabad-224229, Uttar Pradesh, India \\ *Corresponding author
}

\section{A B S T R A C T}

\begin{tabular}{l}
\hline Ke y w o r d s \\
Insecticide \\
Molecules, \\
Scirpophaga \\
incertulas, Dead \\
hearts, White \\
earheads and rice \\
Article Info \\
\hline $\begin{array}{l}\text { Accepted: } \\
21 \text { March } 2020 \\
\text { Available Online: } \\
10 \text { April } 2020\end{array}$ \\
\hline
\end{tabular}

Field experiment was conducted at Crop Research Station, Narendra Deva University of Agriculture and Technology, Kumarganj, Faizabad, Uttar Pradeshto evaluate new molecules of insecticides, viz., Fipronil 5\%SC, Imidacloprid 17.8\%SL, Chlorantaniliprole 0.4G, Cartap hydrochloride 50\% SP, Carbofuran 3G, Monocrotophos 36\%SL and Carbosulfan 6G against yellow stem borer, Scirpophaga incertulas infesting rice during kharif, 2015-16. All the tested insecticides showed varied nature of efficacy against S.incertulas which minimizes the incidence of dead hearts caused by S.incertulas in rice after first days of insecticides application along with white ear heads after second days of insecticides application as compared to water spray i.e. untreated control. However, the lowest number of dead hearts and white ear heads of rice was recorded by liquid insecticides than granular insecticides. Among the tested insecticides, Fipronil 5\%SCwas reduced the dead heart of rice after first dose of insecticide application and it also reduced the white ear heads of rice after second dose of insecticide application at 3,10 and 15 days, respectively. The order of efficacy of tested insecticides after first dose of insecticides application was Fipronil 5\% SC > Chlorantaniliprole 0.4G > Carbosulfan 6G > Carbofuran $3 \mathrm{G}>$ Cartap hydrochloride $50 \% \mathrm{SP}>$ Imidacloprid $17.8 \% \mathrm{SL}>$ Monocrotophos $36 \% \mathrm{SL}$. While, the order of efficacy of tested insecticides was recorded to be Fipronil 5\%SC > Carbosulfan 6G $\geq$ Cartap hydrochloride 50\%SP $>$ Chlorantaniliprole $0.4 \mathrm{G}>$ Carbofuran $3 \mathrm{G}>$ Monocrotophos $36 \% \mathrm{SL}>$ Imidacloprid $17.8 \% \mathrm{SL}$, respectively after second dose of insecticides application.

\section{Introduction}

Rice belongs to the family Oryza sativa L. and most important cereal crops after maize, wheat, bajara and sorghum. It provides food to the world as a major source of the food energy for more than half of the human population. India is world's second largest rice producer and consumer next to China. In
India, rice is grown in almost half of the states, with West Bengal leading the way in terms of production 14.712 million tones, followed by Uttar Pradesh (12.22 million tones and Andhra Pradesh (11.57 million tons) as per Agricultural Statistics 2014-15 Ministry of Agricultural and farmers welfare of the Government of India. In India, rice crop are infested by the more than seventy 
pest and twenty pests are of regular occurrence (Pathak, 1975). Yadav et al., 2019 reported that incidence of rice insect pests like yellow stem borer Sciropophaga incertulas, Leaf folder Cnapholocris medinalis, Rice hispa, Dicladispa armigera, Green leaf hopper, Nephotettix spp. and Grass hopper, Hieroglyphus banian were observed at different growth stages of rice under Uttar Pradesh conditions. Further they reported that maximum population of $S$. incertulas was recorded (5.16 per five sweeps) at $39^{\text {th }}$ standard week's and during this period the temperature was ranged from $22.30^{\circ} \mathrm{C}$ to $30.70^{\circ} \mathrm{C}$ and 58.60 per cent of relative humidity. The $S$. incertulas is the most dangerous pests which can cause severe damage and yield loss to the rice crop in the later stage (Yadav et al., 2019). In India, S. incertulas have assumed to be number one pest status and attacks the rice crop at all growth stages (Pasulu et al., 2002). This pest either causes dead hearts at tillering stage or produces white ears at harvest stage, which can lead to complete failure of the crop (Yadav et al., 2019). The application of insecticides finds to be the prime importance when the pest reaches at above economic threshold level. So that damage caused by the pest should be minimizes to a certain level and which might be help in getting a measurable yield. However, haphazard application of conventional insecticides have a problem in respect of showing undesirable effects like environmental pollution, development of resistance in target pest, and resurgence of pest (Hassall, 1990). In the search of newer group of insecticides with novel mode of action are tested for the control of $S$. incertulas to know the outcome of that particular insecticide on the targeted pest. Keeping this in view the field experiment was conducted to test the efficacy of new molecules of chemical insecticides such as Fipronil, Imidacloprid, Chlorantaniliprole, Cartap hydrochloride, Carbofuran,
Monocrotophos and Carbosulfan insecticides against borer $S$. incertulas.

\section{Materials and Methods}

The field experiment was carried out to evaluate new insecticide molecules against rice yellow stem borer in rice variety Pusa Basmati-1 comprising of eight treatments and three replications including the untreated control treatment with randomized block design during kharif, 2015 at Crop Research Station, Narendra Deva University of Agriculture and Technology, Kumarganj, Faizabad which fall under the subtropical region in indo-gangatic plains and lies at 26.4 North latitude and $82.12^{\circ} \mathrm{E}$ east longitude at an altitude of 113 meter from mean sea level. The fields were having sandy loam soil condition. Total experimental plot size measured $1500 \mathrm{~m}^{2}$. The seedlings were transplanted in the experimental plot with spacing $20 \mathrm{~cm}$ between plant to plant and 15 $\mathrm{cm}$ row to row. 25 days old seedlings of Pusa Basmati-1 rice variety were transplanted $25^{\text {th }}$ July 2015 from the nursery sown 24 days ago, in experimental year. The normal cultural practices were performed throughout the growing season of the crop. The insecticides used in experiment were Fipronil 5\%SC @ 50g/ha (Tr. Name: Regent, M/S Bayer Crop Science Ltd., Mumbai.), Imidacloprid 17.8\%SL @20g/ha (Tr. Name: Confider, Excel Crop Care Limited, Mumbai), Chlorantaniliprole 0.4G @ 40g/ha (Tr. Name: Coragan, Excel Crop Care Limited, Mumbai), Cartap hydrochloride 50\%SP @500g/ha (Tr. Name: Nidan, M/S Dhanuka Agritech Ltd., Gurgaon), Carbofuran 3G @750g/ha (Tr. Name: Furadan, M/S Dhanuka Agritech Ltd., Gurgaon), Monocrotophos 36\%SL @ 500g/ha (tr. Name: Nuvacron, M/S Dhanuka Agritech Ltd., Gurgaon) and Carbosulfan 6G @ 1000g/ha (Tr. Name: Sevin, M/S Dhanuka Agritech Ltd., Gurgaon). The insecticides were applied when dead hearts reached ETL 
i.e. at 5 per cent level. The granular insecticides like Chlorantaniliprole $0.4 \mathrm{G}$, Carbofuran 3G and Carbosulfan 6G were broadcasted in the field. The remaining insecticides viz., Fipronil 5SC, Imidacloprid 17.8SL, Cartap hydrochloride 50SP and Monocrotophos 36SC were sprayed in their respective doses by diluting in sufficient amount of water (based on crop stage) with the help of Knapsack sprayer fitted with hollowcone nozzle. The efficacy of various insecticides against rice stem borer was judged on the basis of the per cent dead heart (DH) at one day before and at 3,10 and 15 days after treatment and white earheads (WE) at grain filling stage. The total number of tillers/panicles and total damaged tillers (DH /WE) were counted on 10 randomly selected hills in each plot for calculating the damaged per cent with following formula.

$$
\% \text { Damage }=\frac{\text { Total numbre of dead hearts or white earheads/hills }}{\text { Total no. of tillers } / \text { hills }} \times 100
$$

The data obtained from the field experiments were analyzed in a randomized block design by ' $F$ ' test for significance by using WASP 1.0 software. Critical difference values were calculated at $5 \%$ probability level and the treatment mean values of the experiment were compared using Duncan's Multiple Range Test (DMRT).

\section{Results and Discussion}

The yellow stem borer infestation was observed at 30 days after transplanting. The first application of insecticides was done when the damage caused by yellow stem borer reached at ETL. In the pre treatment i.e. before application of insecticides the incidence of dead heart was ranged from 4.24 to 5.83 per cent dead hearts/hill. First spray of insecticides were applied after three days of incidence of dead hearts and borer infestations were recorded to be minimum at 1.70 per cent/hill to maximum at 3.50 per cent/hill. It was observed that all the treatment with insecticides spray was found to be an effective against $S$.incertulas and significantly superior over the untreated control i.e water spray. At first dose of application of granular insecticides, the performance of granular insecticides indicates that carbosulfan $6 \mathrm{G}$ was registered superior with lowest per cent of dead hearts after 3 days of application and next was registered by Chlorantaniliprole $0.4 \mathrm{G}$ and highest per cent of dead hearts registered by carbofuran $3 \mathrm{G}$. While, after 10 days of application, the Chlorantaniliprole $0.4 \mathrm{G}$ was recorded lowest per cent of dead hearts and next was registered by carbosulfan 6G and highest per cent of dead hearts registered by carbofuran 3G. However, similar trend of dead hearts was recorded after 15 days of application of granular insecticides. At second dose of application of granular insecticides, the performance of granular insecticides indicates that Chlorantaniliprole $0.4 \mathrm{G}$ was registered superior with lowest per cent of dead hearts after 3 days of application and found to be at par with carbosulfan 6G and highest per cent of dead hearts registered by carbofuran $3 \mathrm{G}$. The similar trend was observed at after 10 days of application but at 15days after application of granular insecticides, the lowest white earheads was recorded in the carbosulfan $6 \mathrm{G}$ followed by carbosulfan $6 \mathrm{G}$ whereas, highest white earheads was recorded in the carbofuran 3G. The mean value of analysis indicate that at first dose of application of granular insecticides, overall performance of granular insecticides indicates that Chlorantaniliprole $0.4 \mathrm{G}$ was registered superior with lowest per cent of dead hearts at first (2.24\%) dose of application and next was registered by carbosulfan $6 \mathrm{G}$ and highest per 
cent of dead hearts registered by carbofuran 3G. While, at second dose of application of granular insecticides, overall performance of granular insecticides indicates that carbosulfan $6 \mathrm{G}$ was registered superior with lowest per cent of white earheads at first $(2.24 \%)$ and next was registered by Chlorantaniliprole $0.4 \mathrm{G}$ and highest per cent of dead hearts registered by carbofuran 3G.These findings are in concern with Sontakke and Dash (2000) evaluated that the application of carbofuran significantly reduced the attack of stem borer causing white heads in rice than cartap hydrochloride. Similarly, Karthikeyan and Purushothaman (2000) noted that that application of carbofuran showed more effective in reducing the rice pest i.e. leaf folder. The results also in agreement with Hugar et al., (2009) who suggested that instead of carbofuran $3 \mathrm{G}$, the carbosulfan $6 \mathrm{G}$ was found to be more effective in the managaement of $S$. incertulas in aerobic rice. The efficacy of liquid insecticides indicates that at 3 day after first spray, the dead heart damage ranged from 1.66 to 3.53 per cent/hill. Among the tested insecticides Fipronil 5\%SC recorded the lowest incidence of dead heart damage of 1.66 and Monocrotophos 36SL which recorded highest $3.53(10.82 \%)$ per cent/hill dead hearts. It was found that all the liquid insecticidal treatments were superior overwater spray. Similar trend was observed upto10 days after spray. A decline in dead heart damage was observed from 3 days after spray and continued upto 15days after spray. Similarly, performance of tested insecticides after second spray was also found to be superior over untreated control i.e water spray. However, among the tested insecticide Fipronil 5\%SC recorded the lowest white earheads damage $(2.13 \%)$ and the insecticide Imidacloprid $17.8 \% \mathrm{SL}$ was recorded highest white earheads $(4.13 \%)$. Similar trend was observed up to 10days after spray. A decline in white earheads damage was observed from
3 days after spray and continued up to 15days after spray. However, the mean value indicate that among all the treatments with insecticides the Fipronil 5\% SC was found to be most effective and significantly superior over rest of the treatments in reducing the dead hearts to minimum level of 1.64 per cent after first spray and maximum per cent of white earheads was recorded in the insecticides Monocrotophos 36SL. Similarly, overall performance of the tested insecticide after second spray also showed maximum reduction in the white earheads than water spray treatment. The mean value of second spray indicate that 2.24 percent i.e. minimum number of white earheads were recorded in the treatment Fipronil $5 \mathrm{SC}$ and maximum number of white earheads was recorded in the insecticide Imidaclorpid 17.8SL (4.02\%). The results of the present investigations are in accord with Dash and Mukherjee (2003) who showed that application of fipronil 5SC at $0.075 \mathrm{~kg}$ a.i./ha against $S$. incertulas were reduced the incidence of dead hearts/hill as compared to the other tested insecticides such as lambda cyhalothrin.

Similarly, Panda et al., (2004) and Singh et al., (2005) also found that application of fipronil 5SC was @ 750g a.i.ha were minimizes the damage caused by $S$. incertulas in rice. The results are also in accordance with Hugar et al., (2007) who managed the $S$. incertulas by application of fipronil 0.3G @ $7.5 \mathrm{~g} \mathrm{a}$.i/ ha and concluded that fipronil 0.3G was found to be most effective insecticide than carbosulfan $6 \mathrm{G}$, carbofuran $3 \mathrm{G}$, cartap hydrochloride $4 \mathrm{G}$, beta-cyfluthrin $2.5 \mathrm{EC}$, monocrotophos 36SL and flubendiamide 500SC, indoxacarb 14.5SC and imidacloprid 17.8SL. In the present investigation, the lowest number of dead hearts and white earheads of rice was recorded by liquid insecticides than granular insecticides (Table $1)$. 
Table.1 Efficacy of various newer insecticide against rice yellow stem borer during 2015

\begin{tabular}{|c|c|c|c|c|c|c|c|c|c|c|}
\hline \multirow[t]{3}{*}{ Treatments } & \multirow{3}{*}{$\begin{array}{l}\text { Dose } \\
\text { (g/a. } \\
\text { i/ha) }\end{array}$} & \multicolumn{7}{|c|}{ Mean percent damage by yellow stem borer } & \multicolumn{2}{|c|}{ Application Mean } \\
\hline & & \multirow{2}{*}{$\begin{array}{l}\text { Pre } \\
\text { treatment }\end{array}$} & \multicolumn{3}{|c|}{ First application } & \multicolumn{3}{|c|}{ Second application } & \multirow[t]{2}{*}{ First } & \multirow[t]{2}{*}{ Second } \\
\hline & & & 3DAS & 10DAS & 15DAS & 3 DAS & 10DAS & 15DAS & & \\
\hline Fipronil 5 SC & 50 & $\begin{array}{c}4.24 \\
(2.17)\end{array}$ & $\begin{array}{c}2.20 \mathrm{~cd} \\
(8.49)\end{array}$ & $\begin{array}{l}2.26 \mathrm{de} \\
(8.60)\end{array}$ & $\begin{array}{c}2.26 \mathrm{~cd} \\
(8.60)\end{array}$ & $\begin{array}{l}2.80 \mathrm{~cd} \\
(9.13)\end{array}$ & $\begin{array}{l}2.66 \mathrm{c} \\
(8.60)\end{array}$ & $\begin{array}{l}2.53 \mathrm{~cd} \\
(9.13)\end{array}$ & $\begin{array}{l}2.24 \mathrm{~cd} \\
(8.56)\end{array}$ & $\begin{array}{l}2.66 \text { cde } \\
(9.37)\end{array}$ \\
\hline Imidacloprid 17.8 SC & 20 & $\begin{array}{l}5.54 \\
(2.45)\end{array}$ & $\begin{array}{l}3.46 \mathrm{~b} \\
(10.71)\end{array}$ & $\begin{array}{l}3.33 \mathrm{de} \\
(8.49)\end{array}$ & $\begin{array}{l}3.00 \mathrm{bc} \\
(10.40)\end{array}$ & $\begin{array}{l}4.13 \mathrm{~b} \\
(11.43)\end{array}$ & $\begin{array}{c}3.86 \mathrm{~b} \\
(11.52)\end{array}$ & $\begin{array}{l}3.93 \mathrm{~b} \\
(11.43)\end{array}$ & $\begin{array}{c}3.26 \mathrm{~b} \\
(10.36)\end{array}$ & $\begin{array}{l}4.02 \mathrm{~b} \\
(11.55)\end{array}$ \\
\hline $\begin{array}{c}\text { Chlorantaniliprole } 0.4 \\
\text { G }\end{array}$ & 40 & $\begin{array}{c}5.33 \\
(2.41)\end{array}$ & $\begin{array}{l}2.33 \mathrm{~cd} \\
(8.73)\end{array}$ & $\begin{array}{l}2.20 \mathrm{bc} \\
(10.50)\end{array}$ & $\begin{array}{c}2.13 \mathrm{~cd} \\
(8.34)\end{array}$ & $\begin{array}{l}2.80 \mathrm{~cd} \\
(9.26)\end{array}$ & $\begin{array}{l}2.53 \mathrm{bc} \\
(9.60)\end{array}$ & $\begin{array}{l}2.60 \mathrm{~cd} \\
(9.26)\end{array}$ & $\begin{array}{l}2.22 \mathrm{~cd} \\
(8.52)\end{array}$ & $\begin{array}{l}2.73 \text { cde } \\
(9.46)\end{array}$ \\
\hline $\begin{array}{c}\text { Cartap } \\
\text { hydrochloride 50 SP }\end{array}$ & 500 & $\begin{array}{c}4.33 \\
(2.19)\end{array}$ & $\begin{array}{l}3.00 \mathrm{bc} \\
(9.96)\end{array}$ & $\begin{array}{c}2.86 \mathrm{bcd} \\
(9.73)\end{array}$ & $\begin{array}{l}2.80 \mathrm{bcd} \\
(9.60)\end{array}$ & $\begin{array}{l}2.73 \mathrm{~cd} \\
(9.42)\end{array}$ & $\begin{array}{c}2.60 \mathrm{bc} \\
(9.16)\end{array}$ & $\begin{array}{l}2.73 \mathrm{~cd} \\
(9.32)\end{array}$ & $\begin{array}{c}2.89 \mathrm{bc} \\
(9.35)\end{array}$ & $\begin{array}{c}2.66 \mathrm{de} \\
(9.29)\end{array}$ \\
\hline Carbofuran 3.0 G & 750 & $\begin{array}{c}4.16 \\
(2.15)\end{array}$ & $\begin{array}{l}2.73 \mathrm{bc} \\
(9.46)\end{array}$ & $\begin{array}{c}2.60 \mathrm{~cd} \\
(9.24)\end{array}$ & $\begin{array}{l}2.66 \mathrm{bcd} \\
(9.35)\end{array}$ & $\begin{array}{l}3.23 \mathrm{~cd} \\
(9.35)\end{array}$ & $\begin{array}{l}3.24 \mathrm{bc} \\
(10.24)\end{array}$ & $\begin{array}{l}2.66 \mathrm{bc} \\
(10.09)\end{array}$ & $\begin{array}{l}2.66 \mathrm{bc} \\
(9.35)\end{array}$ & $\begin{array}{l}3.21 \mathrm{bc} \\
(10.18)\end{array}$ \\
\hline Monocrotophos 36 SL & 500 & $\begin{array}{c}5.83 \\
(2.51)\end{array}$ & $\begin{array}{l}3.53 \mathrm{~b} \\
(10.82)\end{array}$ & $\begin{array}{c}3.46 \mathrm{~b} \\
(10.72)\end{array}$ & $\begin{array}{c}3.33 \mathrm{~b} \\
(11.42)\end{array}$ & $\begin{array}{l}3.46 \mathrm{bc} \\
(10.15)\end{array}$ & $\begin{array}{l}3.46 \mathrm{bc} \\
(10.71)\end{array}$ & $\begin{array}{l}3.33 \mathrm{bc} \\
(10.51)\end{array}$ & $\begin{array}{c}3.44 \mathrm{~b} \\
(10.68)\end{array}$ & $\begin{array}{l}3.42 \mathrm{bc} \\
(10.65)\end{array}$ \\
\hline Carbosulfan 6 G & 1000 & $\begin{array}{l}5.43 \\
(2.43)\end{array}$ & $\begin{array}{l}1.66 \mathrm{~d} \\
(7.36)\end{array}$ & $\begin{array}{l}1.66 \mathrm{e} \\
(7.39)\end{array}$ & $\begin{array}{l}1.60 \mathrm{~d} \\
(7.20)\end{array}$ & $\begin{array}{l}2.13 \mathrm{~d} \\
(8.41)\end{array}$ & $\begin{array}{l}2.40 \mathrm{c} \\
(8.82)\end{array}$ & $\begin{array}{l}2.20 \mathrm{~d} \\
(8.41)\end{array}$ & $\begin{array}{l}1.64 \mathrm{~d} \\
(7.32)\end{array}$ & $\begin{array}{l}2.24 \mathrm{e} \\
(8.51)\end{array}$ \\
\hline Water spray & & $\begin{array}{l}5.52 \\
(2.45)\end{array}$ & $\begin{array}{l}11.20 \mathrm{a} \\
(19.50)\end{array}$ & $\begin{array}{r}11.33 \mathrm{a} \\
(19.46)\end{array}$ & $\begin{array}{c}10.00 \mathrm{a} \\
(18.30)\end{array}$ & $\begin{array}{l}12.60 \mathrm{a} \\
(19.96)\end{array}$ & $\begin{array}{r}13.00 \mathrm{a} \\
(21.00)\end{array}$ & $\begin{array}{r}11.66 \mathrm{a} \\
(19.96)\end{array}$ & $\begin{array}{r}10.84 a \\
(19.18)\end{array}$ & $\begin{array}{r}12.42 \mathrm{a} \\
(20.63)\end{array}$ \\
\hline CD at $0.5 \%$ & & 0.26 & 1.79 & 1.40 & 2.65 & 1.59 & 2.37 & 1.40 & 1.78 & 1.31 \\
\hline CD at $0.1 \%$ & & 0.58 & 2.48 & 1.95 & 3.69 & 2.21 & 3.29 & 1.95 & 2.47 & 1.82 \\
\hline
\end{tabular}

Figure in the parenthesis are arcsin transformation before analysis. 
The results of the present investigation indicate that efficacy of tested insecticides against $S$. incertulas was varied from each other and it might be due to the presence of different molecules in insecticides, different application technique, used water and regional climatic conditions, respectively.

\section{References}

Dash, A. N. and Mukherjee, S. K. (2003). Insecticidal control of major insect pest of rice. Pest Mgmt. Econ. Zool. 11(2): 147-151.

Hassall, K. A. (1990). Biochemistry and use of pesticides. Macmillan press LTD., Hound mills, Basing stoke, Hampshire and Loandon. 536. pp. 121-246.

Hugar, S. V., Naik, M. I. and Manjunatha, M. (2007). Evaluation of new chemical molecules for the management of Scirpophaga incertulas (Walker) in aerobic rice. Karnataka J. Agric. Sci. 22(4): 911-913.

Hugar, S.V., Hosamani, V., Pradeep, S and Hanumanthaswamy, B.C. (2009). Evaluation of New Chemical Molecules for the Management of Scirpophaga incertulas Walker, in Aerobic rice. Int. J. Pl. Prot. 2 (2): 205-208.
Karthikeyan, K. and Purushothaman, S. M. (2000). Efficacy of carbosulfan against rice stem borer, Scripophaga incertulas walker (Pyralidae, Lepidoptera) in rabi crop. Indian J. Pl. Prot. 28 (2): 212214.

Panda, B. M., Rath, L. K. and Dash, D. (2004). Effect of fipronil on yellow stem borer $S$. incertulus Walker and certain plant growth parameters in rice. Indian J. Ent., 66 (1): 17-19.

Pasulu, I. C., Krishnaiah, N. V., Kotti, G. and Varma, N. R. G. (2002). IPM in rice mitr. pp. 45-55.

Pathak, M. D. (1975). Insect pests of rice. International Rice Research Institute, Los banos, Philippines. p. 68.

Singh, J., Suri, K. S. and Saro, P. S. (2005). Efficacy of granular insecticides against rice stem borer on Basmati rice in Punjab. Indian J. Ent., 67 (3): 234-237

Sontakke, B. K and Dash, A. N.(2000). Field efficacy of some new granular insecticides against major pests of rice. Indian J. Ento. 62:353-357.

Yadav A., Gupta, P. K. and Kurulkar, U. (2019). Incidence of Insect-Pests on Rice in Faizabad. Int.J.Curr.Microbiol.App.Sci. $\quad 8(06)$ : 551-555.

\section{How to cite this article:}

Yadav Abhinandan and Gupta, P. K. 2020. Evaluation of New Insecticide Molecules against Rice Yellow Stem Borer Scirpophaga incertulas Walker (Pyralidae: Lepidoptera) under Faizabad Condition. Int.J.Curr.Microbiol.App.Sci. 9(04): 2772-2777. doi: https://doi.org/10.20546/ijcmas.2020.904.327 